PREPRINT, to be published as: Steiner, Tobias (2018). "Bron/Broen, the Pilot as Space between Cultures, and (re)negotiations of Nordic Noir". In: The Scandinavian Invasion: The Nordic Noir Phenomenon and Beyond. ed. / Richard McCulloch; William Proctor. Peter Lang, (forthcoming).

\title{
Bron/Broen, the Pilot as Space between Cultures, and (re)negotiations of Nordic Noir
}

Tobias Steiner, University of Hamburg

As evidenced by the wealth of contributions to this anthology, Nordic Noir has, since the early-2000s, evolved into a globally-popular genre that now easily transcends media-specific boundaries. Television has always been at the forefront of that development: Scandinavian TV productions either turned literary successes such as the Henning Mankell novel universe of Wallander into distinct and easily-recognizable television scripts, or developed independent shows such as Forbrydelsen (DR, 2007-12), which, with foreign adaptations such as The Killing (US) (AMC/Netflix, 2011-14) - themselves grew into international format successes.

The most recent wave of Nordic Noirs - including blockbuster shows like Bron/Broen [The Bridge] (DK/SWE, 2011-), Dicte (DK, 2012-), Blå ögon [Blue Eyes] (SWE, 2014), Arvingerne [The Legacy] (DK, 2014-), Frikjent [Acquitted] (NOR, 2015-), Herrens veje [Rides upon the Storm] (DK, in development) or Kongen af Danmark [The King] (DK, in development, 2017-) - continues to employ a particular Nordic Noir template. But while doing so, many of these shows also simultaneously transform Nordic Noir through processes of remaking and adaptation that become evident in examples such as Gomorrah (ITA, 2014-) and Les Témoins [Witnesses] (FR, 2015), within correspondingly-changing generic, narrative, and locational contexts such as 'Italian' or 'French Noir'. This most recent wave thus both affirms and dissolves the specificity of Nordic Noir as a genre.

This chapter is particularly interested in the status that Nordic Noir as a genre has as a source for formatting within television, and the specific (re)negotiations that take place when Nordic Noir is transferred to different cultural settings. Following a brief introductory framing of Nordic Noir and its role in larger processes of the global format trade, I will use the analytic perspective of Performance Studies which, as I argue, allows for a more nuanced view on the workings behind the circulation of Nordic Noir formats in the global television business. In particular, I will employ Navarro's understanding of format adaptation as processual 'space 
PREPRINT, to be published as: Steiner, Tobias (2018). "Bron/Broen, the Pilot as Space between Cultures, and (re)negotiations of Nordic Noir". In: The Scandinavian Invasion: The Nordic Noir Phenomenon and Beyond. ed. / Richard McCulloch; William Proctor. Peter Lang, (forthcoming).

between cultures' (2012), and try to identify the onsets of this liminal space in the specific setting of the pilot. It is exactly here, I argue, where adaptation processes first become visible processes that take a known template and rework it via narrative modulation into transcultural TV remakes.

Subsequently, I will illustrate this perspective via the example of Bron/Broen, one of the recent Nordic Noir television series that has itself become a format - travelling on a global scale and thus renegotiating the meaning of Nordic Noir in a variety of cultural settings. This will be done via a comparative analysis of Bron/Broen's pilot and two of its international iterations - The Bridge (US), and The Tunnel (FR/UK).

\section{Nordic Noir on TV: Genre and format}

Nordic Noir as a genre has developed out of two classifications taken from the realm of cinema - those of Film Noir and Neo Noir. The Crime Drama subgenre of Film Noir of the 1940s and 50 s stressed the importance of melancholy and desperation behind its often-tragic narratives. This focus was mirrored in its usage of low-key lighting, an emphasis on light and shadow, and unusual camera placements. Later, the Neo Noir of the 1970s modified this dark narrative and visual style by adding (post-)modern themes that reflected more on societal problems such as technological advancements and their social ramifications, identity crises, and corresponding issues of remembering, disillusionment, disorientation and subjectivity (cf. Conard 2007; Waade/Jensen 2013: 193).

The earliest example of Nordic Noir may be traced back to Swedish authors Maj Sjöwall and Per Wahlöö, who, with Roseanna (1965), brought the character of Superintendent Martin Beck to life - a detective protagonist who would eventually form the centre of a ten-novel literary universe (collectively titled 'The Story of a Crime'). As outlined by Daniel Brodén, the narrative structure of the Beck universe follows standard detective crime patterns, but also adds a particularly Nordic, and sometimes Marxist, take on life that highlights a distinctly-voiced social critique of Swedish welfare society and corresponding problems arising from that setting which interfere with the protagonist's work and private life (cf. Brodén 2011).

Starting during the early 1990s, and far from what still is commonly perceived as a UScentric evolution, the larger geographic region that includes Denmark, Sweden and Norway - as well as, in some definitions, also Finland and Iceland - has itself developed highly-productive 
PREPRINT, to be published as: Steiner, Tobias (2018). "Bron/Broen, the Pilot as Space between Cultures, and (re)negotiations of Nordic Noir". In: The Scandinavian Invasion: The Nordic Noir Phenomenon and Beyond. ed. / Richard McCulloch; William Proctor. Peter Lang, (forthcoming).

television ecosystems. Similar to the advancements towards showrunner-led complex television that begun to transform the US market since the 1980s, these Scandinavian TV production systems were able to set high standards both in content and in form (cf. Bondebjerg \& Bono 1996; Bondebjerg \& Redvall 2011; Jensen in this volume).

Scandinavian public broadcasting houses such as Sveriges Television (SVT), the public broadcaster Danmarks Radio (DR), and the Norwegian public broadcaster Norsk rikskringkasting (NRK) have internalized this production system, which has become widely known for its production strategy of the 'Four Dogmas'. 'The active evolution governed by these four dogmas led to the rise of a particularly Scandinavian way of producing long-running shows. Both Sjöwall and Wahlöö's literary universe, and the later emergence of Henning Mankell's Wallander universe in 1991 have, with Beck (1997-2009, 2015-) and Wallander (1995-2003, 2005-2013), subsequently crossed into the world of television series. Along with other examples such as Forbrydelsen and Borgen (DR, 2010-13), Nordic Noir shows have since captured national, regional and international audiences, thus turning the genre into a reliable source for global format trade.

\section{Glocalization Dynamics, Format Adaptation, and Performance Theory}

Television formats can be understood as an epitomization of contemporary cultural exchange that is part of our globally connected world. More than that, television formatting is not solely a contemporary phenomenon or a product of recent globalization trends, but rather 'an essential component of the very logic of television' (Oren \& Shahaf 2012: 19). On a level of production, television formats are thought to represent the 'total body of knowledge systematically and consciously assembled to facilitate the future adaptation under license of the programme'. (Moran 2006: 07) But as Ellis et al. have recently contended, '[t]heoretically no consensus has yet been found on what exactly is a TV format and how it should be understood.' (2016: 3).

The hybridization of television content, together with the emergence of transnational trading structures, advanced conglomeratization, and the technological evolution of easy transmission on a global scale through digital distribution along the lines of the larger processes

${ }^{1}$ According to Waade and Jensen, there exist up to 15 dogmas, but usually only the essential ones - namely 'One Vision', 'Double Story', 'Crossover' and 'Producers Choice' - are highlighted. (cf. 2013: 197). 
PREPRINT, to be published as: Steiner, Tobias (2018). "Bron/Broen, the Pilot as Space between Cultures, and (re)negotiations of Nordic Noir". In: The Scandinavian Invasion: The Nordic Noir Phenomenon and Beyond. ed. / Richard McCulloch; William Proctor. Peter Lang, (forthcoming).

of convergence, have massively helped to open the most recent phase of '[formatting] as significant worldwide business' (2000-present) (Moran 2013: 10). Even more, formats emerge as a 'global trading system that is characterized by [...] rapid international expansion [... and the emergence] of a global value chain' (Chalaby 2016, 65). ${ }^{2}$

This worldwide business that had been fuelled by the massive interest in Reality TV output during the turn of the millennium, also brought with it a first wave of format research that has largely been focused on legal and economic aspects, e.g. sales, advertising, rights management, and the circulation of tried-and-successful formulae in a variety of iterations. Only fairly recently have drama and comedy shows such as Yo Soy Betty, La Fea (RCN, 1999-2001), and also Nordic Noir exponents such as Wallander and Forbrydelsen, evolved from local TV fare to global format adaptation phenomena on a larger scale.

Scrutinizing this delayed evolution, Jean Chalaby has identified inherent obstacles that drama television has to face: any fictional genre 'adaptation must go beyond copycat television and reactualize the script for a new audience' (Chalaby 2016: 170). This reactualization, or 'remapping' (Forrest and Martínez 2015), through transcultural exchange is usually subsumed under the umbrella term of 'cultural adaptation'. Adaptation in a general sense is understood here along the lines of Linda Hutcheon, who defines it as a recombinatory process that forms a 'mixture of repetition and difference, of familiarity and novelty' (Hutcheon \& O'Flynn 2013: 114), allowing for a creative and interpretative modulation of topics, characters, perspectives and/or events. Repurposing Thomas Leitch's influential definition of the film remake as a particular adaptation subset, I use the term 'transcultural remake' in order to refer to an adaptation 'of a given story to a new discursive incarnation within the same mode of representation' (1990: 138), in this case, television.

As a methodological aside and based on cultural-philosophical Wittgensteinian readings such as Wolfgang Welsch's (1999), I prefer using a transcultural focus (hence 'transcultural remake'). For Welsch, this particular focus reveals the complexities inherent in the multitude of differences and similarities of contemporary cultures - an active form of 'external networking' as a result of contemporary cultural entanglement, and overall cultural 'hybridization, [since, for] every culture, all other cultures have tendencially come to be inner-content or satellites.' (ibid: 197-8). Straubhaar's influential paradigm of 'cultural proximity' can be understood as a different

${ }^{2}$ For a more detailed account of the TV format global value chain as singular transnational space, see Chalaby 2016, chapter 4 (pp. 65-90). 
PREPRINT, to be published as: Steiner, Tobias (2018). "Bron/Broen, the Pilot as Space between Cultures, and (re)negotiations of Nordic Noir". In: The Scandinavian Invasion: The Nordic Noir Phenomenon and Beyond. ed. / Richard McCulloch; William Proctor. Peter Lang, (forthcoming).

perspective on Welsch's notion of external networking and hybridization, adhering to the 'seemingly common attraction audiences feel for cultural products [...] that are close in cultural content and style to the audience's own culture(s)' (Straubhaar 2007: 26). While Straubhaar's paradigm still proves an 'important factor in rendering an individual fictional product accessible in different cultures' (Hepp 2015: 140), recent research on glocalized TV has begun to question easy dichotomies between the local and the global. ${ }^{3}$ An increasing number of travelling formats - including Nordic Noir examples such as Forbrydelsen and Män som hatar kvinnor [The Girl With The Dragon Tattoo] (see McCulloch in this volume) - defy an easy logic of the local vs. the global, because they successfully flow across a variety of markets that cannot be explained with cultural proximities alone. ${ }^{4}$ All in all, recent models such as Chalaby's 'global format value chain' (2016: 65) shed light on many of the complexities inherent in the transnational production, programming and reception processes. Doing so, they help to further disentangle the intricate 'multi-layered processes of transculturation' (Hepp 2015: 154) that take place in the global network of contemporary television cultures.

As has been mentioned earlier, format adaptation research has largely been focused on economic and legal issues along the lines of Glocalization dynamics. In order to shed light more on the processes behind the multi-layered transculturation processes that take place when television shows become adapted, Vinicious Navarro has suggested an addition of Performance theory to the debate. He suggests a change of perspective away from an econo-centric focus on generic reproduction and the promise of iterative adaptability, towards a more Cultural Studiesbased focus on the actual processes at play when cultural artefacts travel from one cultural context to another, e.g. how the translation from one cultural setting to another - and corresponding negotiations of cultural values - is facilitated. (Navarro 2012)

Through his exemplary analysis of formatting as performance that identifies a 'space between cultures', Navarro shows that 'the very process emerges as active formatting, articulating different elements together within the matrix of available cultural, national and

${ }^{3}$ cf. e.g. Stehling 2013; Eichner \& Waade 2015; Agger 2011; Turnbull 2016; García Avis 2015; Oren 2012; Perkins \& Verevis 2015, Esser 2016.

${ }^{4}$ For a concise overview of the multiplicity of dimensions on which television formats travel, see e.g. the excellent introduction to a recent special issue of VIEW by John Ellis, Andrea Esser and Juan Francisco Gutiérrez Lozano (2016). 
PREPRINT, to be published as: Steiner, Tobias (2018). "Bron/Broen, the Pilot as Space between Cultures, and (re)negotiations of Nordic Noir". In: The Scandinavian Invasion: The Nordic Noir Phenomenon and Beyond. ed. / Richard McCulloch; William Proctor. Peter Lang, (forthcoming).

industrial context. Adaptations thus interpret, actualize, and redefine format, rather than insert 'variable elements' into an 'invariable' formula.' (Oren \& Shahaf, 2012: 7)

Building on this approach, I argue that such processes of interpretation and actualization become imminently visible in the pilot episode of each remake. According to Jason Mittell, television pilots 'must orient viewers to the intrinsic norms that the series will employ, presenting its narrative strategies so we can attune ourselves to its storytelling style.' (2015: 56) In addition to the numerous functions they usually fulfill, ${ }^{5}$ I argue that in the context of transcultural remakes, pilot episodes furthermore have to make visible their origins by referencing the template they derive from, and by explicitly envisioning the derivation that will, in the future, become the new show aka. remake. Therefore, I argue that the pilot itself represents a condensed manifestation of the overall adaptation process, thus making visible the 'space between cultures' as laid out by Navarro.

In order to exemplify this particular perspective, I will conduct a comparative analysis of Bron/Broen and its two remakes, thus hoping to be able to scrutinize how the show's specific template becomes renegotiated within this 'space between cultures'.

\section{Enter Bron/Broen}

The Danish-Swedish production Bron/Broen (DR1/SVT1, 2011-) has been co-produced by Filmlance International and Nimbus Film and was also co-funded by other media companies such as the Norwegian NRK and German ZDF, as well as by Swedish film funds Film i Väst, Film i Skåne, and Pan-Scandinavian fund Nordisk Film og TV Fond. It has also been sponsored by the MEDIA Programme of the European Union.

The show's basic premise is a dead body centred on the Danish/Swedish border that divides the Øresund Bridge - an incident that triggers an investigation of a Danish and a Swedish inspector who grudgingly have to share jurisdiction and work together to find the killer. Evolving from that premise is a thriller that implicitly challenges its audience to consider current social topics such as racism and inequality, and demonstrates familiar elements of Nordic crime series' significant style and societal critique. Similar to earlier Nordic Noirs such as The Killing and

\footnotetext{
${ }^{5}$ Mittell lists a variety of 'educational' and 'inspirational' functions such as setting the narrative tone, providing orientation, introduce the key set of characters, etc. (2015: 56f.)
} 
Borgen, Bron/Broen also links public, social and cultural issues to the private life stories of the protagonists in complex ways. The postmodern twist of stereotypes and gender roles that, according to Gunhild Agger, comprise a particularly significant feature of recent Nordic Noirs (2011: 114), is also manifest in Bron/Broen and mirrored in the character of Saga Norén (Sofia Helin) - a strong female lead who also has to cope with deep and complex emotional and psychological problems (see Pheasant-Kelly in this volume).

The international success of Bron/Broen as one of the most recent Nordic Noirs has been overwhelming. While the original show was sold to more than 150 countries, ${ }^{6}$ the practice of dubbing even further expanded its market potential. Translated/dubbed versions quickly found enthusiastic audiences in the UK and ancillary English-language markets with the subtitled The Bridge (BBC4, 2012-), while the dubbed version Die Brücke - Transit in den Tod (ZDF, 2012-) made the show available for the German-speaking market. These numbers confirm Sue Turnbull's assertion that with 'the rise of pay television, satellite and digital distribution, and the associated emergence of niche channels and cable networks, it is now possible for a television crime drama in a language other than English to find an enthusiastic and receptive audience well beyond its original centre of production.' (Turnbull 2016: 97)

Furthermore, Bron/Broen has also been sold as a format that allowed adaptations of the show to transplant the Nordic Noir feel into other local settings. Currently, there exist two ${ }^{7}$ format adaptations: On the one hand, there is The Bridge (US) (FX/Endemol Shine America, 201314), which adds a US/Mexican border context with a focus on the Bridge of the Americas that crosses the Río Grande and connects the Mexican city of Ciudad Juárez with the US border city of El Paso. And on the other hand, there is The Tunnel (Canal+/Sky Atlantic, 2013-), which transforms the border narrative towards the context of the French/British border through the Channel Tunnel between Calais, France, and Folkestone, UK. ${ }^{8}$

${ }^{6}$ The Telegraph's Clive James (2014) mentions 174 countries.

${ }^{7}$ On April 4, 2016, The Guardian's Jasper Jackson reported that Russian broadcaster NTV has commissioned a third format adaptation that transplants the Nordic Noir template towards the Russian-Estonian border, with plans to air in 2017.

${ }^{8}$ For more detailed accounts of Bron/Broen's production, trade and reception, see the chapters by Janet McCabe and $\mathrm{lb}$ Bondebjerg in this volume. 
PREPRINT, to be published as: Steiner, Tobias (2018). "Bron/Broen, the Pilot as Space between Cultures, and (re)negotiations of Nordic Noir". In: The Scandinavian Invasion: The Nordic Noir Phenomenon and Beyond. ed. / Richard McCulloch; William Proctor. Peter Lang, (forthcoming).

Bron/Broen: 2-minute pilot template walk-through

Bron/Broen's pilot opens with a close-up of an unidentified driver, whom we follow along his way through a sleeping town and then on an open road The Driver soon reaches the Danish border, and heads towards a huge illuminated bridge that the avid Europhile viewer might quickly identify as the iconic Øresund Bridge. A panoramic shot of the illuminated bridge depicts a long, vibrant line of traffic moving through the bridge's pylons when suddenly, the lights on the bridge are switched off one by one, and the car trail disperses towards the bridge's ends.

We are brought in medias res with a control room where nondescript officials discuss the blackout of the bridge's illumination system. Meanwhile, a lone car approaches the bridge's centre, then stops. We see the car's rear lights and opening boot door, then a solitary person emerges from the car and begins working on something yet unclear. Soon, we discern the driver as marking a line on the ground with powder, then hauls. something out of the trunk, then returns to the car, starts the engine and leaves the scene.

Back in the control room, we follow a confused radio conversation about the possible causes for this technical breakdown. Then, cut to a police car approaching a yet-nondescript crime scene on the bridge. We're introduced to a male detective who finds a female corpse centred on a thick yellow line demarcating the actual border. Next is a cut to black, and opening titles.

The described sequence delineates the first two minutes of Bron/Broen's pilot episode, in which the audience is introduced to the initial crime and the protagonists. As Mittell notes, television pilots 'provide exposition for the story and situation that will drive the series, establish engaging characters, set the show's tone, and make viewers want to see future episodes' (2010: 50). This certainly holds true for Bron/Broen's pilot episode. As I will show, the Swedish/Danish original's transcultural remakes present such an exposition in similar ways and, somewhat metaconsciously, also on the levels of aesthetics and the mise-en-scène.

\section{Comparing Bron/Broen and its format adaptations}

Comparing Bron/Broen's opening sequence to The Bridge (US), it quickly becomes clear that the US version mimics the original's opening sequence even on the visual level, down to an imitation of the cut rate and rhythm of images. The Tunnel employs a similar strategy, although 
PREPRINT, to be published as: Steiner, Tobias (2018). "Bron/Broen, the Pilot as Space between Cultures, and (re)negotiations of Nordic Noir". In: The Scandinavian Invasion: The Nordic Noir Phenomenon and Beyond. ed. / Richard McCulloch; William Proctor. Peter Lang, (forthcoming).

taking a more liberal stance. But very soon, the adaptations then depart from this imitative style and negotiate and adapt the original Nordic Noir theme along the lines of their respective narrative universes.

The Bridge (US) plays with the visual template of the Nordic Noir and transplants it into the setting of the US-Mexican border. On a visual level, the Northern European coolness purveyed by the Nordic Noir imagery of an almost frosty colour palette of bleached grey, green and blue tones (cf. Jensen \& Waade 2013) becomes 'Americanized' through a change to the warmer colours of lush brown, red and orange-yellow tones (see screenshots). The typically mellow Nordic Noir darkness of Bron/Broen's visual setup gets transferred into a more extreme and vibrant version, with crisper colours and more distinct darkness that supposedly is more to the liking of US American audiences, because the visual effects seemingly echo tried-andsuccessful aesthetic strategies known from the CSI franchise (cf. Allen 2007; Turnbull 2016) and other popular US crime dramas such as The Shield (FX, 2002-8).

Of course, it can be argued that the colour scheme is, quite obviously, the first elements that need to be localized: and due to the narrative shift from cold Scandinavia to the hot desert region of the US/Mexican border, ${ }^{9}$ the colour palette ought to reflect that. But there are a variety of ways to do this, and to me, the producers' conscious choice to select a glossy, vibrant visual style poses a clear indication that the show wanted to consciously present itself as an American crime drama in the tradition of $C S I$ and its generic brethren.

On the other hand, the French/British version of The Tunnel chose to basically stick with the overall visual style of the Danish/Swedish Nordic Noir, although a slight shift from blue-greys to grey-green-browns is noticeable. Nonetheless, the French remake took other liberties of marking its originality, mainly on the level of the narrative.

With sequence $[1]^{10}$, we are right at the beginning of the show, following the yet unknown criminal along his/her way to the crime scene. While at this stage, all three shows use similar ways of presentation, it is important to note that The Tunnel already points towards an inherent

\footnotetext{
${ }^{9}$ As Sue Turnbull notes, the production company's initial choice had been to relocate the Swedish/Danish
} template to a US/Canadian setting. But, "[d]etermined to make the show as different as possible in aesthetic and style to the original, [the showrunners] therefore opted for the Mexican/US border and the possibility of exploring the very complex cultural issues relevant to the El Paso, Texas and Juaréz, Mexico locations.' (Turnbull 2016: 106).

${ }^{10}[\mathrm{x}]$-indices mark key scenes and corresponding screenshots in order to identify similarities and differences regarding the visual setup of each show. 
PREPRINT, to be published as: Steiner, Tobias (2018). "Bron/Broen, the Pilot as Space between Cultures, and (re)negotiations of Nordic Noir". In: The Scandinavian Invasion: The Nordic Noir Phenomenon and Beyond. ed. / Richard McCulloch; William Proctor. Peter Lang, (forthcoming).

meta-consciousness in respect to the original: The Tunnel imitates Bron/Broen's way of initial presentation but twists its plot by shifting from the killer's perspective towards that of an innocent maintenance worker, who discovers the corpus delicti - the female corpse, which is placed on a clearly-visible demarcation between France and the UK. And while the overall composition of this brief sequence is very similar in Bron/Broen and The Bridge, it can be noted that the US version appears to be more active, since we are shown more of what the criminal is actually doing, while Bron/Broen's pilot episode leaves more of that open to the audience's imagination.

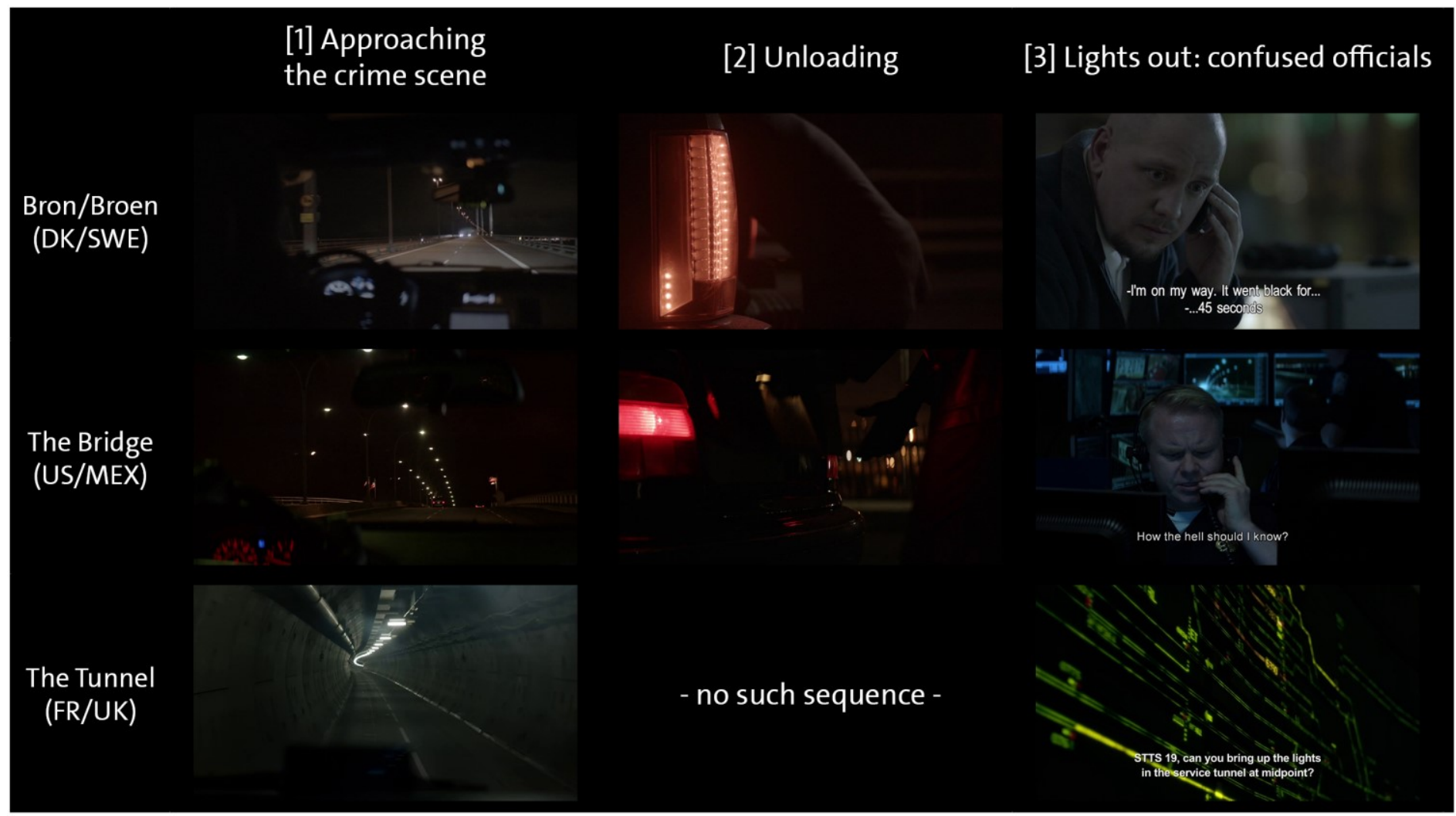

Sequence [3], which has the confused reaction of the officials at its centre, is also realized in quite similar ways. Differences can be identified in Bron/Broen use of 'closer' close-ups that even break the frame, which has the effect of drawing the viewer in. In contrast, The Bridge always makes sure to use neat, standard close-ups with full head framing, which may also be attributed to an 'Americanized' style of filming. Further contrast is added by The Tunnel, which barely uses close-ups at all, interweaving the image of a neon schematics plan with the brief blend-in of a person's face holding a telephone. 
PREPRINT, to be published as: Steiner, Tobias (2018). "Bron/Broen, the Pilot as Space between Cultures, and (re)negotiations of Nordic Noir". In: The Scandinavian Invasion: The Nordic Noir Phenomenon and Beyond. ed. / Richard McCulloch; William Proctor. Peter Lang, (forthcoming).

In sequence [4], the female corpse is introduced to the audience. At this point, the differences between orchestrations are quite remarkable: While Bron/Broen stays consistent with the established visual style during the first few seconds, The Bridge openly contradicts this style by choosing to show the corpse through a surveillance camera perspective. This kind of imagery has by now become a popular staple of US cinema (cf. Zimmer 2015) and television. Here, by mediatizing the victim's body via the surveillance screen, more distance between the viewer and the victim is created. Furthermore, this might also be seen as a critical comment on the US legal system's high-tech surveillance apparatus. In The Tunnel, we at first are barely able to discern the location of the dead body through the maintenance driver's perspective. Here, too, an extra layer of distance is introduced via the maintenance car windshield, but this still feels more imminent and direct than the US version.

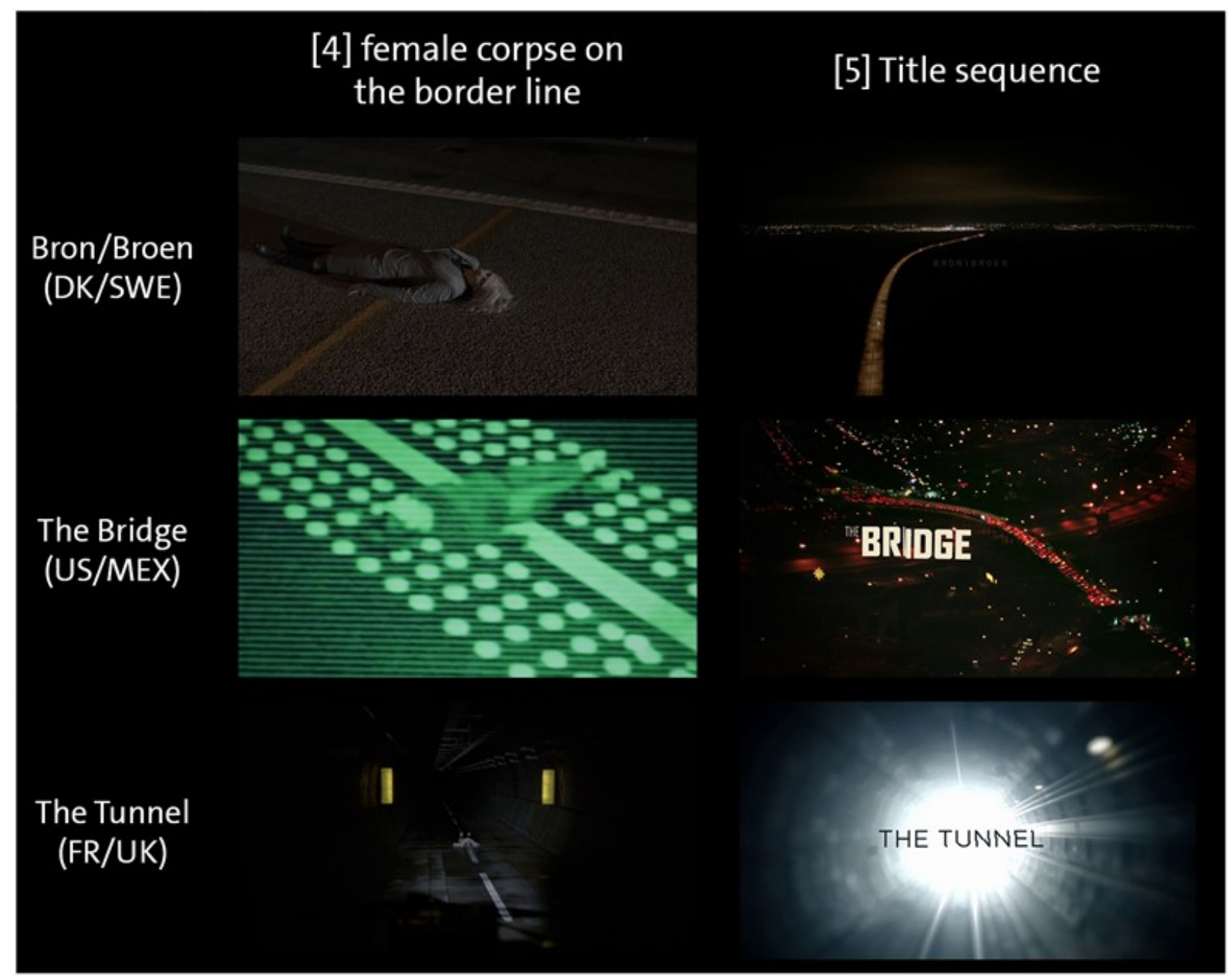


PREPRINT, to be published as: Steiner, Tobias (2018). "Bron/Broen, the Pilot as Space between Cultures, and (re)negotiations of Nordic Noir". In: The Scandinavian Invasion: The Nordic Noir Phenomenon and Beyond. ed. / Richard McCulloch; William Proctor. Peter Lang, (forthcoming).

Cut to the opening titles [5]. It is here where the differences become most visible. Bron/Broen uses panoramic shots of the Øresund region and finally ends on a dark and low-key aerial shot of the iconic Øresund Bridge, next to which its opening title is imposed in subtle yellow-brown letters. In contrast, the US remake makes use of a potpourri of local imagery, introducing life on the border between the United States and Mexico. As Sue Turnbull notes:

This encompasses daytime scenes in the desert under white-hot light and night time scenes of chiaroscuro gloom in the backstreets of Juaréz. [...] Sources of light are muted and faces barely distinguishable except for the light reflecting on sweating brows and cheekbones. The overall effect is one of discomfort, threat and danger. (2016: 107)

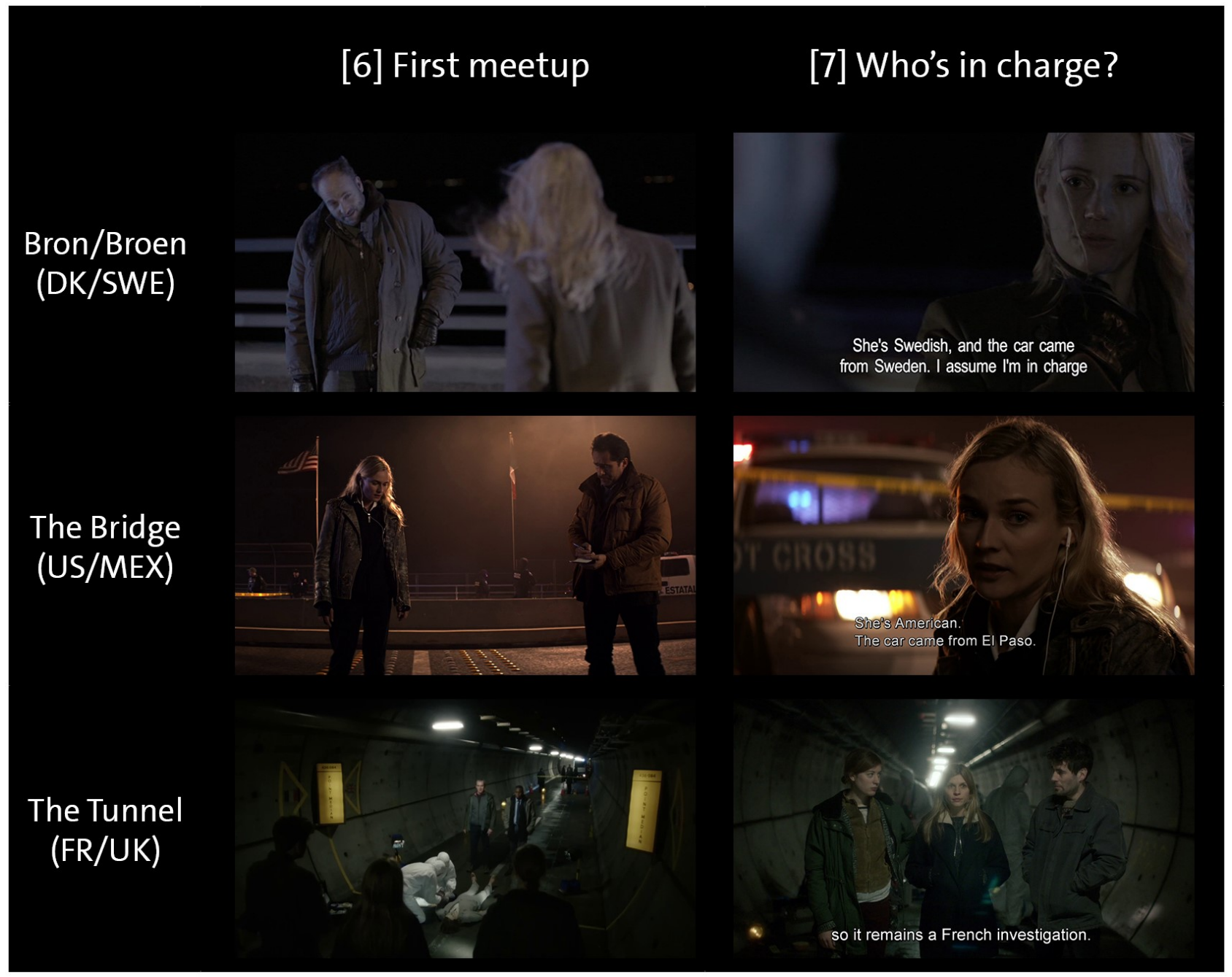

And while Bron/Broen and The Bridge (US) use this sequence to establish a sense of location and placement, the French/British version uses panning zoom shots that depict details 
PREPRINT, to be published as: Steiner, Tobias (2018). "Bron/Broen, the Pilot as Space between Cultures, and (re)negotiations of Nordic Noir". In: The Scandinavian Invasion: The Nordic Noir Phenomenon and Beyond. ed. / Richard McCulloch; William Proctor. Peter Lang, (forthcoming).

of the channel tunnel and the actual crime scene that is part of the evolving narrative. The title sequence's climax then refrains from using any markers of place or locality, but simply visualizes a 'from-the-darkness-into-the-light' effect that the avid train traveller may recall from the experience when leaving a tunnel. This is done in extreme, from total black that fades into blinding whiteness, with the title font imposed in the centre of the image. A feature that unites all of the shows is the actual styling of the title fonts: during all three title interludes, the respective title first fades into view, and then becomes divided into two parts via a stylized fracture that symbolizes a demarcation line.

Samples [6] and [7] have been added to illustrate further differences building up between the two pilots. In Bron/Broen, this part of the narrative follows the title sequence's interlude, and in both The Bridge and The Tunnel, it is part of the introductory sequence that precedes the opening title sequence. Each of the iterations play out the popular crime drama trope of the mismatched investigator couple, but their initial realizations differ significantly. The original Nordic Noir template of Bron/Broen uses a distanced over-the-shoulder perspective, while the US version continues its use of standardized medium close-ups with corresponding national flags in the background [6], openly pointing out the conflict inherent in the different sociocultural backgrounds of these two characters. The same goes for The Tunnel, where the visual setup is even more distanced, and the multifaceted gap between the two characters further metaphorized via similar markers of national territories.

Sample [7] also indicates differences in the overall setup when the female detectives - the Swedish Saga Norén, American Sonya Cross (Diane Kruger) and French Elise Wassermann (Clémence Poésy) - declare their respective responsibilities as primary contacts for the case. On the level of aesthetics, these three key scenes differ strongly from each other: while Saga, in an over-the-shoulder close-up that breaks the frame, is framed by darkness and hardly recognizable due to her long hair blowing across the screen, Sonya, in standard centred close up, is framed by police car lights that emphasize her features. Further contrast is added by The Tunnel's Elise, who is framed in a medium shot that encompasses not only her, but also two French colleagues, both of whom seem surprised when she declares the case a French investigation.

While a more detailed discussion of the three series' expanding narrative worlds regrettably lies beyond the scope of this chapter, ${ }^{11}$ let me just point out some more points of volume)

\footnotetext{
${ }^{11}$ For a more expansive discussion and analysis of Bron/Broen's characters, see e.g. Pheasant-Kelly (this
} 
PREPRINT, to be published as: Steiner, Tobias (2018). "Bron/Broen, the Pilot as Space between Cultures, and (re)negotiations of Nordic Noir". In: The Scandinavian Invasion: The Nordic Noir Phenomenon and Beyond. ed. / Richard McCulloch; William Proctor. Peter Lang, (forthcoming).

divergence that evolve out of the early phases of each show's pilot episode. While Bron/Broenin true Nordic Noir fashion - voices social critique through the killer's plotline, this narrative thread is completely lost in the context of the US remake, arguably because American audiences might be perceived as not being able to relate to the 'foreign' Scandinavian concept of the social welfare state. As Forrest and Martínez suggest: "The specificity of the remake's regional problems forces the vengeance narrative to recede before the social plagues of femicide, predatory abuse of illegal migrants, drug trafficking, and official corruption." (2015: 728).

Furthermore, elements of locality such as the use of iconic places and buildings (the $\emptyset$ resund Bridge, the Little Mermaid of Copenhagen, etc.) and the distinct use of nuanced language differences and corresponding puns and tensions - all crucial ingredients of Bron/Broen - have been traded for more clear-cut differences in The Bridge, where American English is the narrative's governing language. For Nordic Noir, the factor of place and locality - or 'local colour', as Eichner and Waade have recently labelled it - has become a crucial production value (cf. Jensen \& Waade 2013; Eichner \& Waade 2015, García Avis 2015). The US remake explicitly turns away from these Nordic Noir elements and simplifies its plot structure towards a more generic detective drama, arguably adding a further level of 'Americanization' to the show. As Michael L. Wayne has recently argued, cable channel FX 'was not particularly concerned with making Broen/Bron's narrative work for an undifferentiated mass of American viewers'. Rather, the show was soon tailored to fit the 'traditionally masculine appeal' and brand identity of FX, and its main target audience of white male 18-49-year-olds (Wayne 2016).

Another noteworthy element is the differences that are recognizable in the ways the sequences are edited: while Bron/Broen's initial sequence (up to the fade to black and opening titles) lasts approximately 2:10 minutes, The Bridge (US) only needs 1:30 minutes to tell the same story. The increased narrative pace of more than $25 \%$, which is mainly achieved via faster cut rates and fewer 'lingering shots' that, in Bron/Broen, help to establish the distinct Nordic Noir atmosphere, ultimately also adds to the general impression of a more streamlined 'Americanized' and 'masculine' style.

The Tunnel, on the other hand, has its own strategy of adapting Nordic Noir: with a similar choice of colour palette and lighting, it stays closer to Bron/Broen's Nordic Noir template, but it also quickly becomes clear during the pilot's first minutes that the approach is, in many aspects, a distinctly different one. Starting with the transfer of the initial narrative setting from the wide, open space that is the Øresund Bridge towards the dense, claustrophobic confines of one of the maintenance tunnels of the Euro Tunnel, to the narrative choice of introducing the plot through 
the perspective of a non-related maintenance worker who happens to find the victim's dead body on one of his routine checks - The Tunnel sets itself apart from the Danish/Swedish original in many ways. In terms of locality, The Tunnel, similar to The Bridge (US), puts the use of languages on its head: while Bron/Broen was able to play with the linguistic similarities and differences between the Danish and the Swedish language, The Tunnel openly addresses the linguistic difficulties inherent in cross-border communication, thus adding its own version of comic situations to the plot when the protagonists Elise Wassermann and Karl Roebuck (Stephen Dillane) fail to properly communicate with each other. Regarding narrative pace, The Tunnel feels closer to the Nordic original: the show does actually expand its introductory segment and reveals more details about the dead body and also introduces the protagonists. Doing so, it takes five minutes before the first opening titles are shown. ${ }^{12}$

Nordic Noir and the pilot as Space between Cultures

Following Navarro, format adaptations inhabit a sort of 'space between cultures, a site in which difference emerges out of imitation, where hierarchical distinctions are both upheld and upset, and from where one culture looks at and interprets another' (ibid. 2012: 34).

In the preceding paragraphs, I have argued that when looking at the case of Bron/Broen and its transcultural remakes, traces of Navarro's 'space between cultures' can be found in the distinct form of the television pilot. Adhering to their introductory functions, the transcultural remakes of The Bridge (US) and The Tunnel (FR/UK) present their narrative expositions in similar ways - both refer back to, and thus acknowledge, the template or 'original' on which they are based. Both iterations introduce a narrative universe defined by the complexities intrinsic to life within a border region - involving a constant exchange and renegotiation with the Other - and both feature transplanted elements of Nordic Noir in their narratives. What I found surprising, then, is the fact that both format adaptations also boldly posit themselves as fully aware of the intricacies inherent in the format trade. This becomes imminently visible in The Bridge: the US remake mimics Bron/Broen's opening sequence even down to the cut rate and rhythm of images.

${ }^{12}$ This might also be attributed to a different editing strategy in order to fill programming slots that might also switch to the first commercial break after this introductory part. 
Doing so, these transcultural remakes cite, adapt, and thus transform the 'original' show's template.

But soon, these shows, like musical improvisations, then depart from an imitative style. They negotiate and adapt the original's themes along the lines of their respective narrative universes, eventually dissolving visual similarities into analogies, and then completely diverging along with their distinct plotlines. Out of their origin's template, they evolve towards something both strangely familiar and intriguingly new.

As I hope to have been able to show via the examples discussed here, this evolution is far from being determined by container cultures or an 'assumption that adaptation is carried out mainly to take account of "national sensibilities"' (Esser 2016: 19). Rather, each transcultural remake negotiates its narrative on a variety of levels, ranging from the distinctly local premise of one channel's brand image and target audience (as was largely the case with FX and The Bridge, cf. Wayne 2016), to the larger socio-cultural implications arising from the collaboration of two national broadcasters - as is the case with Canal+ and Sky Atlantic, who also cater to distinct French- and English-speaking target audiences with The Tunnel. As an outlook, it would be more than worthwile to see in what ways the Russian-Estonian iteration (which is still in development, cf. Jackson 2016) will negotiate the transcultural remake of the Nordic Noir template.

All in all, it is fascinating how Nordic Noir has left an impressive mark on the global television market. And, as a genre, Nordic Noir has begun to encompass further renegotiation processes: through adaptation into different locational and generic settings, the focus on crime drama has by now also expanded to encompass history series such as 1864 (DR, 2015-) and political drama such as Borgen, Bedrag [Follow the Money] (DR, 2015-) and Kongen af Danmark [The King]. Furthermore, the fact that shows such as Lillyhammer (Netflix, NRK 2012-14), Shetland (BBC, 2013-), Y Gwyll [Hinterland] (S4C/BBC, 2013-), Gomorrah (Sky Italia 2014-), Les Témoins [Witnesses] (La Une, Channel 2 BEL/FR 2015-), Marseille (Netflix FR, 2016), and Marcella (ITV UK, 2016), which are not even produced by Scandinavian television outlets, and have also lost all relation to Scandinavia, are also included in the larger debate around Nordic Noir, thus definitely hinting at the transcultural category that the genre has become. 
PREPRINT, to be published as: Steiner, Tobias (2018). "Bron/Broen, the Pilot as Space between Cultures, and (re)negotiations of Nordic Noir". In: The Scandinavian Invasion: The Nordic Noir Phenomenon and Beyond. ed. / Richard McCulloch; William Proctor. Peter Lang, (forthcoming).

\section{References}

Agger, G. (2011). Emotion, Gender and Genre: Investigating The Killing. Northern Lights: Film and Media Studies Yearbook, 9(1), pp. 111-125. doi:10.1386/nl.9.111_1

Allen, M. (Ed.). (2007). Reading CSI: Crime TV Under the Microscope. London, New York: I.B. Tauris.

Bondebjerg, l., \& Bono, F. (1996). Television in Scandinavia: History, Politics and Aesthetics. Luton: University of Luton Press.

Bondebjerg, I., \& Redvall, E. N. (2011). A Small Region in a Global World: Patterns in Scandinavian Film and TV Culture. CEMES Working Papers. http://lup.lub.lu.se/record/1734599

Brodén, D. (2011). The Dark Ambivalences of the Welfare State: Investigating the Transformations of the Swedish Crime Film. Northern Lights: Film and Media Studies Yearbook, 9(1), 95-109. doi:10.1386/nl.9.95_1

Chalaby, J. K. (2016). The Format Age: Television's Entertainment Revolution. Cambridge: Malden, MA; Polity Press.

Conard, M. T. (ed.). (2007). Philosophy of Popular Culture. The Philosophy of Neo-Noir. Lexington: University Press of Kentucky.

Eichner, S., \& Waade, A. M. (2015). Local Colour in German and Danish Television Drama: Tatort and Bron//Broen. Global Media Journal - German Edition, 5(1). Retrieved from http://www.globalmediajournal.de/2015/07/18/local-colour-in-german-and-danishtelevision-drama-tatort-and-bronbroen-2/.

Ellis, J., Esser, A., \& Gutiérrez Lozano, J. F. (2016). Editorial. VIEW Journal of European Television History and Culture, 5, 1-5. doi:10.18146/2213-0969.2016.jethc098

Esser, A. (2016) 'Defining 'the Local' in Localization or 'Adapting for Whom?', in Esser, A., Smith, I. R. and Bernal-Merino, M. A. (eds) Media across borders. Localising TV, film and video games, pp. 19-35. Basingstoke, Taylor \& Francis Ltd, pp. 19-35.

Forrest, J., \& Martínez, S. (2015). Remapping Socio-Cultural Specificity in the American Remake of The Bridge. Continuum, 29(5), 718-730. doi:10.1080/10304312.2015.1068725

García Avis, I. (2015) 'Adapting Landscape and Place in Transcultural Remakes: The Case of Bron|Broen, The Bridge and The Tunnel', SERIES - International Journal of TV Serial Narratives, vol. 1, no. 2, pp. 127-138. doi: 10.6092/issn.2421-454X/5898

Hepp, A. (2015). Transcultural Communication. Hoboken: Wiley Blackwell. 
PREPRINT, to be published as: Steiner, Tobias (2018). "Bron/Broen, the Pilot as Space between Cultures, and (re)negotiations of Nordic Noir". In: The Scandinavian Invasion: The Nordic Noir Phenomenon and Beyond. ed. / Richard McCulloch; William Proctor. Peter Lang, (forthcoming).

Hutcheon, L., \& O'Flynn, S. (2013). A Theory of Adaptation (2nd ed.). London, New York: Routledge.

Jackson, J. 'The Bridge: new version to span Russia and Estonia', The Guardian. Retrieved from https://www.theguardian.com/media/2016/apr/04/the-bridge-russia-estonia.

James, C. (2014). The end of The Bridge? I might die of despair. The Telegraph. Retrieved from http://www.telegraph.co.uk/culture/tvandradio/tv-and-radioreviews/10602238/Clive-James-The-end-of-The-Bridge-I-might-die-of-despair.html. Accessed 10 May, 2018.

Jensen, P. M., \& Waade, A. M. (2013). Nordic Noir challenging 'the language of advantage': Setting, light and language as production values in Danish television series. The Journal of Popular Television, 1(2), pp. 259-265. doi:10.1386/jptv.1.2.259_1

Leitch, T. (1990). Twice-Told Tales: The Rhetoric of the Remake. Literature Film Quarterly, 18, 138-149.

McCabe, J., \& Akass, K. (2013). TV's Betty Goes Global: From Telenovela to International Brand. London, New York: I.B. Tauris.

Mittell, J. (2010). Television and American Culture. New York: Oxford University Press.

Mittell, J. (2015). Complex TV: The Poetics of Contemporary Television Storytelling. New York: New York University Press.

Moran, A., \& Malbon, J. (2006). Understanding the Global TV Format. Bristol: Intellect.

Moran, A. (2013). Global Television Formats: Genesis and Growth. Critical Studies in Television: An International Journal of Television Studies, 8(2), 1-19. doi:10.7227/CST.8.2.2

Navarro, V. (2012). More Than Copycat Television: Format Adaptation as Performance. In T. G. Oren \& S. Shahaf (Eds.), Global Television Formats. Circulating Culture, Producing Identity, pp. 23-38. London: Routledge.

Oren, T. G. (2012). Reiterational Texts and Global Imagination: Television Strikes Back. In T. G. Oren \& S. Shahaf (Eds.), Global Television Formats. Circulating Culture, Producing Identity, pp. 366-381. London: Routledge.

Oren, T. G., \& Shahaf, S. (2012). Introduction: Television Formats - A Global Framework for TV Studies. In T. G. Oren \& S. Shahaf (Eds.), Global Television Formats. Circulating Culture, Producing Identity, pp. 1-20. London: Routledge.

Perkins, C., \& Verevis, C. (2015). Transnational Television Remakes. Continuum, 29(5), 677683. doi:10.1080/10304312.2015.1068729 
PREPRINT, to be published as: Steiner, Tobias (2018). "Bron/Broen, the Pilot as Space between Cultures, and (re)negotiations of Nordic Noir". In: The Scandinavian Invasion: The Nordic Noir Phenomenon and Beyond. ed. / Richard McCulloch; William Proctor. Peter Lang, (forthcoming).

Stehling, M. (2013). From Localisation to Translocalisation: Audience Readings of the Television Format Top Model. Critical Studies in Television: An International Journal of Television Studies, 8(2), 36-53. doi:10.7227/CST.8.2.4

Straubhaar, J. D. (2007). World Television: From Global to Local. Thousand Oaks: Sage Publications.

Turnbull, S. (2016). Border Crossings: The Transnational Career of the Crime Drama. In C. Sharp \& M. Leiboff (Eds.), Cultural Legal Studies. Law's Popular Cultures and the Metamorphosis of Law, pp. 95-112. Abingdon, Oxon, New York, NY: Routledge.

Waade, A. M., \& Jensen, P. M. (2013). Nordic Noir Production Values. The Killing and The Bridge. Akademisk kvarter / Academic Quarter, 7. Retrieved from http://www.akademiskkvarter.hum.aau.dk/pdf/vol7/13a AWaadePMJensen Nordic Noir.pdf. Accessed 10 May, 2018.

Wayne, M. L. (2016). Critically Acclaimed and Cancelled: FX's The Bridge. Channel as Brand and the Adaptation of Scripted TV Formats. VIEW Journal of European Television History and Culture, 5. doi:10.18146/2213-0969.2016.jethc107

Welsch, W. (1999). Transculturality - the Puzzling Form of Cultures Today. In Featherstone (Ed.), Spaces of Culture: City, Nation, World (pp. 194-213). Sage Publications.

Zimmer, C. (2015). Surveillance cinema. Postmillennial pop. New York: New York University Press.

\section{Author info}

Tobias Steiner has studied in Hamburg and London and holds an MA in Television Studies from Birkbeck, University of London. He has taught U.S.-American Television history at Universität Hamburg, Germany, and currently works as a research fellow in the fields of open science and open education at the university's Universitätskolleg.

Further information: https://orcid.org/0000-0002-3158-3136 